\title{
Amisulpride: tackling postoperative nausea and vomiting not a nightmare any more
}

\author{
Ajay Kumar ${ }^{1}$, Anuj Singh ${ }^{2 *}$, D. B. S. Brashier ${ }^{3}$, Awanish Karan ${ }^{4}$, S. Sharma ${ }^{5}$, Uday Pratap ${ }^{6}$
}

${ }^{1}$ Department of Anaesthesiology and Critical Care, Mil Hospital, Dehradun, Uttarakhand, India

${ }^{2}$ Department of Anaesthesiology and Critical Care, ${ }^{3}$ Department of Paharmacology, ${ }^{4}$ Department of ENT \& HNS, Government Hospital, Joshimath, Uttarakhand, India

${ }^{5}$ Department of Anaesthesiology and Critical Care, Mil Hospital, Jaipur, Rajasthan, India

${ }^{6}$ Department of Surgery, Central Coast Hospital, Wyong, Australia

Received: 20 May 2020

Revised: 04 June 2020

Accepted: 05 June 2020

\author{
*Correspondence: \\ Dr. Anuj Singh, \\ Email: anujsingh.doc@gmail.com
}

Copyright: () the author(s), publisher and licensee Medip Academy. This is an open-access article distributed under the terms of the Creative Commons Attribution Non-Commercial License, which permits unrestricted non-commercial use, distribution, and reproduction in any medium, provided the original work is properly cited.

\begin{abstract}
Vomiting and nausea remains concern in postoperative patients for anaesthesiologists and surgeons. Patients remain at risk for adverse medical consequences as wound dehiscence, dehydration, electrolyte derangement's and gastric aspiration. This entity delays discharge and is one of the causes of unanticipated admission after ambulatory surgery. Presently dopamine (D2), serotonin (5-HT3), and histamine (H1) antagonists are widely used prophylactic agents, as is the corticosteroid dexamethasone, but the incidence of postoperative nausea and vomiting (PONV) is still appreciable. Safety concerns as QT interval prolongation has led to nearly phasing out of use of D2-antagonist Droperidol, a potent and most favoured formulation. With minimal studies and randomized studies to back up the efficacy of existing modalities viz 5HT-antagonist, promethazine, metoclopramide and dimenhydrinate for management of postoperative nausea and vomiting, need for evaluation, study and incorporation into formulary for management was always persisting. Amisulpride is an anti-psychotic agent, used routinely in >50 countries worldwide is a potent but atypical D2-antagonist with minimal adverse profile mainly QT interval prolongation, extrapyramidal signs and symptoms, which had plagued out other members of same class. In addition to D2 antagonism this drug exhibits potent antagonist action against D3 receptors, implicated in the emetic response. In pre clinical studies and multiple randomized controlled multicenter studies the effectiveness and safety of low dose intra venous Amisulpride was established and approved as Barhemsys @ Acacia Pharma by US Food and drug administration in February 2020. This drug will soon add to protocol-based management of PONV.
\end{abstract}

Keywords: Postoperative nausea and vomiting, D2 antagonist, Amisulpride, QT interval

\section{INTRODUCTION}

Postoperative nausea and vomiting (PONV) are defined as any nausea, retching, or vomiting occurring during the first 24-48 hrs after surgery in in patients. ${ }^{1}$ The physiology of PONV is complex and these complexities need to be resolved by further studies to get it understand adequately. Pathophysiology of vomiting in linked with structures in brain, distributed throughout the medulla oblongata of the brain-stem and not just centralized in an anatomically defined 'vomiting centre'. ${ }^{1}$ The centers involved includes chemoreceptor trigger zone (CRTZ), located at the caudal end of the fourth ventricle in the area postrema, and the nucleus tractus solitarius (NTS), 
located in the area postrema and lower pons. The CRTZ receives input from vagal afferents in the gastrointestinal tract, and it can also detect emetogenic toxins, metabolites, and drugs circulating in the blood and cerebrospinal fluid due to its lack of the blood brain barrier. The CRTZ relays neurons to the NTS which in turn receives input from vagal afferents and from the vestibular and limbic systems and subsequently triggers vomiting by stimulating the rostral nucleus, the nucleus ambiguous, the ventral respiratory group, and the dorsal motor nucleus of the vagus. ${ }^{2}$

Postoperative nausea or vomiting or retching can have adverse medical consequences in post operated patients, as wound dehiscence, dehydration, electrolyte derangement, and aspiration of gastric contents. These events have been the least desired outcome and often delays discharge from PACU., ${ }^{3,4}$ Postoperative nausea, or vomiting is one of the main causes of unanticipated admission after ambulatory surgery, and it adds considerably to resource wastage and costs. ${ }^{5-7}$

There are two commonly followed PONV risk scores for adults and children, consisting of five risk factors, namely female gender, non-smoking status, history of PONV, history of motion sickness, and duration of surgery $>60$ min. ${ }^{8,9}$ If $0,1,2,3,4$, or 5 risk factors are present, the incidence of PONV is postulated as $17 \%, 18 \%, 42 \%$, $54 \%, 74 \%$, and $87 \%$, respectively. Apfel et al subsequently developed a simplified risk score based on data from above observation and previously evaluated data, which could be applied across and curtailed risk factors to four. ${ }^{2}$ The revised score includes female gender, history of PONV and/or motion sickness, non-smoking status, and postoperative use of opioids. The correlation of $0,1,2,3$, or 4 risk factors correlate risk of PONV to $10 \%, 20 \%, 40 \%, 60 \%$, or $80 \%$, respectively.

Risk-based postoperative nausea or vomiting prophylaxis is well established in guidelines, but adherence can be poor and the failure rate exceeds $30 \% .^{10-12}$ At present, prophylaxis most commonly involves 5HT3-antagonists, such as ondansetron, often in combination with dexamethasone. ${ }^{13}$

The recommended antiemetics for PONV are tabulated in Table $1 .^{7}$
Rescue treatment for PONV, after failed prophylaxis, has been evaluated by many studies however no prospective agent or antiemetic has shown promising results. ${ }^{14-20}$ One survey found that repeat dosing with a 5 HT 3-antagonist was common among anaesthesiologists, even though trials have repeatedly shown it to be inefective. ${ }^{18-21}$ Consensus guidelines specially recommend that an antiemetic used to treat postoperative nausea or vomiting should be from a different pharmacologic class to any drugs given prophylactically. ${ }^{10}$ In practice agents, such as promethazine, metoclopramide, and dimenhydrinate, are not supported by evidence from randomized, controlled trials. As compared to they are associated with numerous side effects, including sedation and extrapyramidal side effects, which can result in prolongation of postanesthesia care unit (PACU) stay. There remains, therefore, a significant unmet medical need to evaluate and incorporate a definitive antiemetic for such cases.

The selective dopamine D2/D3-antagonist Amisulpride has been used as an oral antipsychotic for more than $30 \mathrm{yr}$ and has been notable for its favorable side effect profile. ${ }^{22}$ It has been recently shown to be an effective and safe antiemetic when given intravenously at very low doses. $^{23,24}$ Because dopaminergic antiemetics are rarely used nowadays for postoperative nausea or vomiting prophylaxis, this is potentially an attractive mechanism for a rescue antiemetic.

\section{CLINICAL PHARMACOLOGY}

Amisulpride is a dopamine-2 (D2) receptor antagonist. Its chemical name is 4-Amino-N-[(1-ethyl-2-pyrrolidinyl) methyl]-5-(ethylsulfonyl)-o-anisamide. The empirical formula is $\mathrm{C} 17 \mathrm{H} 27 \mathrm{~N} 3 \mathrm{O} 4 \mathrm{~S}$ representing a molecular weight of 369.48. Chemical structure is depicted in Figure 1.25

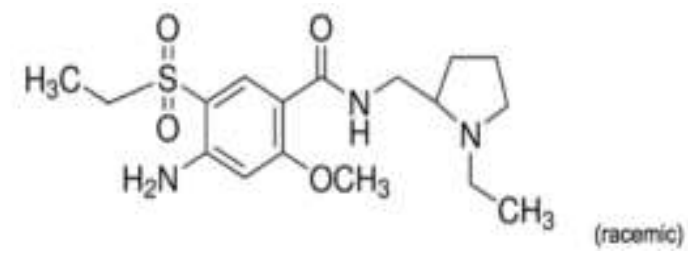

Figure 1: Chemical structure of amisulpride.

Table 1: Recommended antiemetics.

\begin{tabular}{|c|c|c|c|c|}
\hline & Generic name & Route & Dosage (mg) & Timing \\
\hline \multirow{5}{*}{ First class } & Dexamethasone & IV & $4-8$ & Induction \\
\hline & Droperidol & IV & $0.625-1.25$ & End of surgery \\
\hline & Ondansetron & IV & 4 & Induction \\
\hline & Palonosetron & IV & 0.075 & Induction \\
\hline & Aprepitant & Oral & 40 & Before induction \\
\hline \multirow{3}{*}{ Second class } & Dimenhydrinate & IV & 50 & Induction \\
\hline & Scopolamine & Transdermal & 1 & Prior night /day of surgery \\
\hline & Metoclopramide & IV & $25-50$ & Induction \\
\hline
\end{tabular}


Amisulpride is a white or almost white crystalline, nonhygroscopic powder in racemic state and melting point of $126^{\circ} \mathrm{C}$. Practically hydrophilic and sparingly soluble in ethanol this compound is freely soluble in methylene chloride.

\section{MECHANISM OF ACTION}

Amisulpride is a selective dopamine-2 (D2) and dopamine-3 (D3) receptor antagonist. ${ }^{25,26}$ D2 receptors are located in the CTZ and respond to the dopamine released from the nerve endings. ${ }^{4,5}$ Activation of CTZ relays stimuli to the vomiting center, which is involved in emesis. Studies in multiple species indicate that D3 receptors in the area postrema also play a role in emesis. ${ }^{7}$ Amisulpride inhibits emesis caused by apomorphine, with an estimated $\mathrm{ED}_{50}$ of less than $1 \mathrm{mcg} / \mathrm{kg}$, subcutaneously; and inhibits cisplatin induced emesis at $2 \mathrm{mg} / \mathrm{kg}$ and morphine induced emesis at 3 to $6 \mathrm{mg} / \mathrm{kg}$, when given intravenously. ${ }^{26}$ Amisulpride has no appreciable affinity for any other receptor types apart from low affinities for $5-\mathrm{HT}_{2 \mathrm{~B}}$ and $5-\mathrm{HT}_{7}$ receptors. ${ }^{25,29}$

\section{INDICATIONS}

Amisulpride is indicated and approved for usage in adults as prophylaxis for PONV either alone or in conjuction with antiemetic of different class; therepeutic management in patients with failed prophylaxis or afresh in cases with no intake of any other class anti emetic.

\section{DRUG DOSAGE AND FORMULATION}

The recommended dosage of amisulpride for management of PONV is in Table 2. ${ }^{25-28}$

Table 2: Dosage and regimen for PONV management.

\begin{tabular}{|ll|}
\hline Indication & Adult dosage regimen \\
\hline $\begin{array}{l}\text { Prevention } \\
\text { of PONV }\end{array}$ & $\begin{array}{l}\text { Induction of anaesthesia - } 5 \mathrm{mg} \text { intra } \\
\text { venous single dose infused over } 1 \text { to } 2 \\
\text { minutes }\end{array}$ \\
\hline $\begin{array}{l}\text { Treatment } \\
\text { of PONV }\end{array}$ & $\begin{array}{l}\text { Nausea/vomiting postoperative - } 10 \mathrm{mg} \\
\text { intra venous single dose infused over } 1 \\
\text { to } 2 \text { minutes }\end{array}$ \\
\hline
\end{tabular}

\section{Preparation and administration}

Dilution of amisulpride is not required before administration. Amisulpride is chemically and physically compatible with water for Injection, 5\% dextrose injection and $0.9 \%$ sodium chloride injection, which may be used to flush an intravenous line before or after administration.
Protect from light, amisulpride is subject to photo degradation. Administer within 12 hours of removal of the vial from the protective carton.

Prior to administration, inspect the solution visually for particulate matter and discoloration. Discard if particulate matter or discoloration is observed

\section{SIDE EFFECTS}

Bench mark Study involved 1,166 patients treated in placebo-controlled trials..$^{31-35} 748$ of these patients received a dose of $5 \mathrm{mg}$ for prevention of PONV (of whom 572 received another antiemetic concomitantly) and 418 patients received $10 \mathrm{mg}$ for treatment of PONV.

After due analysis of studies carried out main adverse effects noted in study population at incidence of $>2 \%$ are in Table 3.

Table 3: Commonly encountered side effects with use of amisulpride.

\begin{tabular}{|l|l|}
\hline Adverse effect & Incidence (\%) \\
\hline Pain at injection site & 6 \\
\hline Chills & 4 \\
\hline Hypokalemia & 4 \\
\hline Procedural hypotension & 3 \\
\hline Abdominal distension & 2 \\
\hline
\end{tabular}

Prolonged oral use of amisulpride is associated with blood and lymphatic system disorders i.e. agranulocytosis; cardiac disorders i.e. bradycardia, torsa de pointes, ventricular tachycardia, prolonged QT by electrocardiogram; general disorders such as neuroleptic malignant syndrome; immune system disorders such as angioedema, hypersensitivity, urticaria; hepatic disorders such as increased hepatic enzymes; nervous system disorders such as agitation, anxiety, dystonia, extrapyramidal disorder, seizures; psychiatric disorders such as confusional state, insomnia, somnolence and vascular disorders; hypotension. ${ }^{27}$

\section{PHARMACOKINETICS}

After an intravenous infusion, the peak plasma concentration of amisulpride is achieved at the end of the infusion period and the plasma concentration decreases to about $50 \%$ of the peak value within approximately 15 minutes. The AUC $(0-\infty)$ increases dose-proportionally in the dose range from $5 \mathrm{mg}$ to $40 \mathrm{mg}$ (4-times the maximum recommended dose).

The following mean pharmacokinetic parameters of amisulpride were observed following a single 5 or $10 \mathrm{mg}$ intravenous dose in adult healthy subjects and surgical patients. 
Table 4. Pharmacokinetic parameters of amisulpride from clinical studies. ${ }^{28}$

\begin{tabular}{|llllll|} 
& $\begin{array}{l}\text { Single dose } \\
(\mathbf{m g})\end{array}$ & $\begin{array}{l}\text { Infusion duration } \\
\text { (mins) }\end{array}$ & Subjects & $\begin{array}{l}\text { Mean (SD) } \\
\text { Plasma concentration } \\
(\mathbf{n g} / \mathbf{m l})\end{array}$ & $\begin{array}{l}\text { AUC } \\
(\mathbf{n g . h} / \mathbf{m l})\end{array}$ \\
\hline Healthy subject & 5 & 2 & 39 & $200(139)$ & $154(38)$ \\
\hline \multirow{3}{*}{ Patients } & 10 & 1 & 29 & $451(230)$ & $136(28)^{\mathrm{a}}$ \\
& 5 & $1-2$ & $26^{\mathrm{b}}$ & $161(58)$ & $260(65)$ \\
\cline { 2 - 6 } & 10 & $1-2$ & $27^{\mathrm{c}}$ & $127(64)$ & $204(94)$ \\
\hline
\end{tabular}

a:AUC $(0-2 h r)$; b:patients in a clinical trial for prophylaxis of PONV; c:patients in clinical trials for treatment of PONV.

\section{Distribution}

Volume of distribution for amisulpride is estimated to be 127-144 litres in surgical and 171 litres in healthy subjects. Distribution is noted in erythrocytes with plasma protein binding $25-30 \%$ in concentration range 37 to 1850 $\mathrm{ng} / \mathrm{ml} .^{25,30}$

\section{Elimination}

Elimination half-life is approximately 4 to 5 hours. With clearance time of 24 and 21 hours for healthy and surgical patients respectively. ${ }^{25}$

\section{Excretion and elimination}

After an intravenous administration mainly, drug is excreted through urine (58\%) and feces (20\%). ${ }^{15}$

\section{SPECIAL CONSIDERATION}

\section{Pregnancy}

There's insufficient data to establish a negative impact of usage of amisulpride in pregnant women, for risk of major birth defects, adverse maternal or fetal outcomes or miscarriage. Animal studies carried out with multiple variable dosage regimen also concluded, nil impact on maternal pregnancy parameters.

\section{Lactation}

Available studies have demonstrated the presence of amisulpride 11-20 fold higher concentration in human milk in patients taking oral dosage (200-400 mg/day). ${ }^{31}$ There's insufficient data to correlate any adverse effect on breast fed infants. Increase in serum prolactin levels attributed to D2 receptor antagonism, may cause increase in serum prolactin levels and subsequently an increase in maternal milk production.

\section{Renal impairment}

No studies have been conducted on patients with impaired renal functions with ref to eGFR $<30 \mathrm{ml} / \mathrm{min} / 1.73 \mathrm{~m}^{2}$.
However, usage of amilsuplride in patients with severe renal impairment must be avoided to reduce the risk of accumulation in higher doses dude to impaired excretion. $^{34}$

\section{CONTRAINDICATIONS}

Amisulpride is contraindicated in patients with known hypersensitivity to it. Patients with underlying long QT syndrome, prolactinoma, pheochromocytoma.

\section{DRUG INTERACTION}

Reciprocal antagonism is noted with dopamine agonist (levodopa), usage of dopamine agonist with amisulpride is to be avoided. Drugs causing prolongation of QT interval (ondansetron, droperidol, anti malarials) must be used cautiously and under medical supervision.

\section{CLINICAL STUDIES}

The efficacy of $5 \mathrm{mg}$ amisulpride for prevention and management of postoperative nausea vomiting was evaluated in 2 randomised, placebo controlled, double blind studies in patients undergoing surgical intervention under general anaesthesia, for elective surgeries.

In both studies the timing for study drug administration was timed to induction.

\section{Study 1 (USA-342)}

Monotherapy with amisulpride was instituted. ${ }^{31}$

\section{Study 2 (USA and Europe-1,147)}

Amisulpride co administered along with anti-emetic (non -dopimenergic) as ondansetron, dexamaethasone. ${ }^{32}$

In study 1, 342 patients were evaluated and the demography included, mean age 54 years (range 21 to 88 years); $65 \%$ female; $87 \%$ White/Caucasian, $12 \%$ Black, and $1 \%$ Asian race. Matching in terms of risk for PONV with $30 \%$ of patients having two risk factors, $47 \%$ of patients having three risk factors and $23 \%$ of patients having four risk factors were ensured. 
Table 5: Complete response rates in adult patients for the prevention of PONV within 24 hours after end of surgery in studies 1 and 2.

\begin{tabular}{|c|c|c|c|c|}
\hline & \multicolumn{2}{|l|}{ Study 1} & \multicolumn{2}{|l|}{ Study 2} \\
\hline & $\begin{array}{l}\text { Amisulpride } \\
5 \mathrm{mg}(\mathrm{n}=176)\end{array}$ & $\begin{array}{l}\text { Placebo } \\
(n=166)\end{array}$ & $\begin{array}{l}\text { Amisulpride } 5 \mathrm{mg} \\
\text { with another anti emetic } \\
(\mathrm{n}=572)\end{array}$ & $\begin{array}{l}\text { Placebo with another } \\
\text { anti-emetic }(n=572)\end{array}$ \\
\hline Complete response & 78 & 54 & 330 & 268 \\
\hline Difference $(95 \% \text { CI })^{*}$ & $12 \%(2 \%, 22 \%)$ & & $11 \%(5 \%, 17 \%)$ & \\
\hline
\end{tabular}

Un adjusted, nominal $95 \%$ confidence interval.

Table 6: Complete response rates in adult patients for the treatment of PONV within 24 hours after treatment in studies 3 and $4 . .^{33,34}$

\begin{tabular}{|c|c|c|c|c|}
\hline & \multicolumn{2}{|c|}{ Study 3 no prophylaxis ${ }^{a}$} & \multicolumn{2}{|c|}{ Study 4 prior prophylaxis ${ }^{b}$} \\
\hline & $\begin{array}{l}\text { Amisulpride } 10 \mathrm{mg} \\
(\mathrm{n}=188)\end{array}$ & $\begin{array}{r}\text { Placebo } \\
(n=181)\end{array}$ & $\begin{array}{l}\text { Amisulpride } 10 \mathrm{mg} \\
(\mathrm{n}=230)\end{array}$ & $\begin{array}{l}\text { Placebo } \\
(n=235)\end{array}$ \\
\hline Complete response & 59 & 39 & 96 & 67 \\
\hline Difference $(95 \% \text { CI })^{\mathrm{c}}$ & $10 \%(1 \%, 9 \%)$ & & $13 \%(5 \%, 22 \%)$ & \\
\hline
\end{tabular}

a:Excluding emesis within the first 30 minutes; b:received prior PONV prophylaxis with one or more non-dopaminergic antiemetics: a5HT3-antagonist 77\%, dexamethasone in $65 \%$ and another antiemetic class in 10\%; c:unadjusted, nominal $95 \%$ confidence interval.

Study 2 was conducted in the United States and Europe in 1,147 patients. The mean age was 49 years (range 18 to 91 years); 97\% female; 75\% White/Caucasian, $9 \%$ Black, $1 \%$ Asian, and $14 \%$ of unreported race. The treatment groups were similarly matched in terms of risk for PONV with $56 \%$ of patients having three risk factors and $43 \%$ of patients having four risk factors.

Primary efficacy of drug under study was complete response.

Complete response was defined as absence of any episode of emesis or use of any rescue preparation post operatively with in first 24 hours. Results for both trials are shown in Table 5.

The clinical study demonstrated superiority of amisulpride $5 \mathrm{mg}$ in prevention of nausea/vomiting in patients undergoing surgical intervention under general anaesthesia alone as well as with additional antiemetic as compared to placebo.

\section{TREATMENT OF POSTOPERATIVE NAUSEA AND VOMITING}

The efficacy of amisulpride $10 \mathrm{mg}$ as a single dose was evaluated in two randomized, double blind, placebocontrolled, multi-center trials in patients experiencing PONV after general anesthesia and elective surgery.

Study 3: Patients who had not received prior prophylaxis. ${ }^{33}$

Study 4: Patients who had received and failed prophylaxis with an antiemetic of another class. Exclusion was excised in study 4 for patients already received D2 receptor antagonist. ${ }^{34}$

Study 3 included 369 patients with demography as mean age 47 years, range 19 to 82 years; $76 \%$ female; $82 \%$ White/Caucasian, $8 \%$ Black, $2 \%$ Asian, and $8 \%$ of unreported race. Most of the patients had either two risk factors $(36 \%)$ or three risk factors $(53 \%)$ for PONV and these percentages were comparable in treatment groups.

Study 4 included 465 patients with demography as mean age 46 years, range 18 to 85 years; $90 \%$ female; $82 \%$ White/Caucasian, 9\% Black, 3\% Asian, and $6 \%$ of unreported race). Patients had received prior PONV prophylaxis with one or more non-dopaminergic antiemetics: a 5-HT3-antagonist in 77\%, dexamethasone in $65 \%$ and another antiemetic class in $10 \%$. Most of the patients had either three risk factors $(43 \%)$ or four risk factors $(51 \%)$ for PONV and these percentages were similar between treatment groups.

Primary efficacy of drug under study was complete response.

Complete response was defined as absence of any episode of emesis or use of any rescue preparation post operatively with in first 24 hours (excluding emesis with in the first 30 minutes).

Amisulpride complete response in both studies is shown in Table 6.

Study concluded acceptable efficacy of single dose regimen of amisulpride $10 \mathrm{mg}$ for treatment of postoperative nausea and vomiting in patient undergone surgical intervention under general anaesthesia. 
Table 7: Clinical effect in first 24 hrs after treatment.

\begin{tabular}{|c|c|c|c|}
\hline & $\begin{array}{l}\text { Placebo } \\
(n=235)\end{array}$ & $\begin{array}{l}\text { Amisulpride } 5 \text { mg } \\
(\mathrm{n}=237)\end{array}$ & $\begin{array}{l}\text { Amisulpride } 10 \\
\mathrm{mg}(\mathrm{n}=\mathbf{2 3 0})\end{array}$ \\
\hline & $\mathbf{N}(\%)$ & $\mathbf{N}(\%)$ & $\mathbf{N}(\%)$ \\
\hline Complete response $95 \% \mathrm{CI}$ & $67(28.5)$ & $80(33.8)$ & $96(41.7)$ \\
\hline Complete response at $2 \mathrm{hrs}$ & $116(49.4)$ & $134(56.5)$ & $160(69.6)$ \\
\hline Complete response at $4 \mathrm{hrs}$ & $87(37.0)$ & $105(44.3)$ & $136(59.1)$ \\
\hline Complete response at 6 hrs & $77(32.8)$ & $99(41.8)$ & $121(52.6)$ \\
\hline Emesis & $67(28.5)$ & $43(18.1)$ & $36(15.7)$ \\
\hline Use of rescue medication & $163(69.4)$ & $155(65.4)$ & $127(55.2)$ \\
\hline Significant nausea ${ }^{\#}(\geq 4$ on 11 -point verbal rating scale) & $139(59.1)$ & $135(57.0)$ & $111(48.3)$ \\
\hline Any nausea ( $\geq 1$ on 11 -point verbal rating scale) & $181(77.0)$ & $183(77.2)$ & $163(70.9)$ \\
\hline Mean nausea area under curve (0-3 hrs) & 7,629 & 6,995 & 5,638 \\
\hline
\end{tabular}

\# Excluding nausea/emesis events occurring in first $30 \mathrm{~min}$ after treatment.

\section{TREATMENT OF POSTOPERATIVE NAUSEA AND VOMITING COMPARATIVE ANALYSIS OF TWO DOSES}

A multicentric study (study 5) was under taken involving 2,285 adult patients undergoing surgery under general inhalational anesthesia and received standard antiemetic prophylaxis at 23 sites in Canada, France, Germany, and the United States. ${ }^{35}$

702 patients encountered PONV in 24 hours period after surgery, the target population was randomized to receive single dose of 5 or $10 \mathrm{mg}$ intravenous amisulpride or matching placebo.

The primary end point was complete response. Complete response was defined as absence of any episode of emesis or use of any rescue preparation post operatively with in first 24 hours (excluding emesis with in the first 30 minutes).

Secondary endpoints included incidence of emesis and rescue medication use, nausea burden, time to treatment failure, and length of stay in post anaesthesia care unit and hospital.

The above studies established efficacy of amisulpride 10 $\mathrm{mg}$ intravenous dosage over $5 \mathrm{mg}$ formulations for prevention of PONV patients undergoing surgical intervention under general anaesthesia (Table 7).

\section{CONCLUSION}

Amisulpride an anti-psychotic agent, used routinely in $>50$ countries worldwide is a potent but atypical D2antagonist with minimal adverse profile mainly QT interval prolongation, extrapyramidal signs and symptoms, which had plagued out other members of same class. In addition to D2 antagonism this drug exhibits potent antagonist action against D3 receptors also, implicated in the emetic response. In view of above this drug after being evaluated in various studies, with a dosage of $10 \mathrm{mg}$ intravenous administration it will alleviate the need for new antiemetic for patients experiencing PONV. This drug has shown positive results and will soon be added to protocol-based management of PONV in patients with adequate safety. USA FDA has approved amisulpride in February 2020 for use in PONV.

Funding: No funding sources

Conflict of interest: None declared

Ethical approval: Not required

\section{REFERENCES}

1. Diemunsch P, Joshi GP, Brichant JF. Neurokinin-1 receptor antagonists in the prevention of postoperative nausea and vomiting. $\mathrm{Br} \mathrm{J}$ Anaesth. 2009;103:7-13.

2. Apfel CC, Kranke P, Eberhart LH, Roos A, Roewer N. Comparison of predictive models for postoperative nausea and vomiting. $\mathrm{Br} \mathrm{J}$ Anaesth 2002;88:234-40.

3. Macario A, Weinger M, Carney S, Kim A. Which clinical anesthesia outcomes are important to avoid? The perspective of patients. Anesth Analg. 1999;89:652-8.

4. Kranke P, Eberhart LH, Toker H, Roewer N, Wulf H, Kiefer P. A pro-spective evaluation of the POVOC score for the prediction of post-operative vomiting in children. Anesth Analg. 2007;105:1592-7.

5. Hill RP, Lubarsky DA, Phillips-Bute B, Fortney JT, Creed MR, Glass PS, et al. Cost effectiveness of prophylactic antiemetic therapy with ondanse-tron, droperidol, or placebo. Anesthesiology. 2000;92:95867.

6. Fortier J, Chung F, Su J: Unanticipated admission after ambulatory surgery a prospective study. Can $\mathbf{J}$ Anaesth 1998; 45:612-9.

7. Apfel CC, Korttila K, Abdalla M et al. A factorial trial of six interventions for the prevention of postoperative nausea and vomiting. $\mathrm{N}$ Engl $\mathrm{J}$ Med 2004; 350: 2441-51. 
8. Koivuranta M, Läärä E, Snåre L, Alahuhta S. A survey of postoperative nausea and vomiting. Anaesthesia 1997;52:443-9.

9. Chung F, Mezei G: Factors contributing to a prolonged stay after ambulatory surgery. AnesthAnalg 1999; 89:1352-9.

10. Gan TJ, Diemunsch P, Habib AS, Kovac A, Kranke P, Meyer TA, et al. Society for Ambulatory Anesthesia:Consensus guidelines for the management of post-operative nausea and vomiting. Anesth Analg. 2014;118:85-113.

11. Kooij FO, Klok T, Hollmann MW, Kal JE. Automated reminders increase adherence to guidelines for administration of prophylaxis for postoperative nausea and vomiting. Eur J Anaesthesiol. 2010;27:187-91.

12. White PF, O'Hara JF, Roberson CR, Wender RH, Candiotti KA. POST-OP Study Group: The impact of current antiemetic practices on patient outcomes:a prospective study on high-risk patients. Anesth Analg. 2008; 107:452-8.

13. Habib AS, Gan TJ. The use of droperidol before and after the Food and Drug Administration black box warning:A survey of the members of the Society of Ambulatory Anesthesia. J Clin Anesth. 2008;20:35-9.

14. Habib AS, Gan TJ. The effectiveness of rescue antiemetics after failure of prophylaxis with ondansetron or droperidol: A preliminary report. J Clin Anesth. 2005;17:62-5.

15. Habib AS, Chen YT, Taguchi A, Hu XH, Gan TJ. Postoperative nausea and vomiting following inpatient surgeries in a teaching hospital: A retrospective data-base analysis. Curr Med Res Opin. 2006;22:1093-9.

16. Habib AS, Reuveni J, Taguchi A, White WD, Gan TJ. A comparison of ondansetron with promethazine for treating postoperative nausea and vomiting in patients who received prophylaxis with ondansetron:A retrospective database analysis. Anesth Analg. 2007;104:548-51.

17. Meyer TA, Roberson CR, Rajab MH, Davis J, McLeskey CH. Dolasetron versus ondansetron for the treatment of postoperative nausea and vomiting. Anesth Analg. 2005;100:373-7.

18. Kovac AL, O'Connor TA, Pearman MH, Kekoler LJ, Edmondson D, Baughman VL. Efficacy of repeat intravenous dosing of ondansetron in controlling postoperative nausea and vomiting: A randomized, double-blind, placebo-controlled multi-center trial. J Clin Anesth. 1999;11:453-9.

19. Candiotti KA, Nhuch F, Kamat A, Deepika K, Arheart KL, Birnbach DJ, et al. Granisetron versus ondansetron treatment for breakthrough postoperative nausea and vomiting after prophylactic ondansetron failure: A pilot study. Anesth Analg, 2007;104:13703.

20. Candiotti KA, Ahmed SR, Cox D, Gan TJ. Palonosetron versus ondansetron as rescue medication for postoperative nausea and vomiting: A randomized, multicenter, open-label study. BMC Pharmacol Toxicol. 2014;15:45.

21. Macario A, Claybon L, Pergolizzi JV. Anesthesiologists' practice patterns for treatment of postoperative nausea and vomiting in the ambulatory Post Anesthesia Care Unit. BMC Anesthesiol. 2006;6:6

22. Coulouvrat C, Dondey-Nouvel L. Safety of Amisulpride (Solian): A review of 11 clinical studies. Int Clin Psychopharmacol. 1999;14:209-18.

23. Kranke P, Eberhart L, Motsch J, Chassard D, Wallenborn J, Diemunsch P, et al. I.V. APD421 (Amisulpride) prevents postoperative nausea and vomiting:A randomized, double-blind, placebocontrolled, multicentre trial. $\mathrm{Br} \mathrm{J}$ Anaesth. 2013;111:938-45.

24. Gan TJ, Kranke P, Minkowitz HS, Bergese SD, Motsch J, Eberhart L, et al. Intravenous Amisulpride for the prevention of postoperative nausea and vomiting:Two concurrent, randomized, double-blind, placebo-controlled trials. Anesthesiology. 2017;126:268-75.

25. National Center for Biotechnology Information. PubChem Database. Amisulpride, CID=2159. Available at: https://pubchem.ncbi.nlm.nih.gov/ compound/Amisulpride. Accessed on May 172020.

26. Habib AS, Kranke P, Bergese SD, Chung F, Ayad S, Siddiqui N, et al. Amisulpride for the Rescue Treatment of Postoperative Nausea or Vomiting in Patients Failing Prophylaxis:A Randomized, Placebocontrolled Phase III Trial. Anesthesiology. 2019;130:203-12.

27. Kranke P, Bergese SD, Minkowitz HS, Melson TI, Leiman DG, Candiotti KA, et al. Amisulpride Prevents Postoperative Nausea and Vomiting in Patients at High Risk: A Randomized, Double-blind, Placebo-controlled Trial. Anesthesiology. 2018;128(6):1099-106.

28. Rosenzweig P, Canal M, Patat A, Bergougnan L, Zieleniuk I, Bianchetti G. A review of the pharmacokinetics, tolerability and pharmacodynamics of Amisulpride in healthy volunteers. Hum Psychopharmacol. 2002;17(1):1-13.

29. Abbas, AI, Hedlund, PB, Huang X, Tran TB, Meltzer HY, Roth BL. Amisulpride is a potent 5-HT7 antagonist: relevance for antidepressant actions in vivo. Psychopharmacology. 2009;205:119-28.

30. Zhang L, Zhang C, Tang W, He L, Liu Y, Tian DD, et al. Efficacy of Amisulpride on postoperative nausea and vomiting:a systematic review and metaanalysis. Eur J Clin Pharmacol. 2020.

31. US Phase III Study of APD421 in PONV. Available at: https://www.clinicaltrials.gov/ct2/show/NCT0199 1860?term $=$ NCT01991860\&cond $=\% 22$ Postoperative +Nausea+and+Vomiting\%22\&draw $=2 \&$ rank $=1$. Accessed on 3 May 2020.

32. Clinicaltrials. Available at: https://www.clinicaltrials. gov/ct2/results?cond=\&term=NCT02337062\&cntry= $\&$ state $=\&$ city $=\&$ dist $=$. Accessed on 3 May 2020. 
33. Clinicaltrials. Available at: https://www.clinicaltrials. gov/ct2/results?cond=\&term=NCT02449291\&cntry= $\&$ state $=\&$ city $=\&$ dist $=$. Accessed on 3 May 2020.

34. Clinicaltrials. Available at: https://www.clinicaltrials. gov/ct2/results?cond $=\&$ term $=$ NCT02646566\& cntry= $\&$ state $=\&$ city $=\&$ dist $=$. Accessed on 3 May 2020.

35. Habib AS, Kranke P, Bergese SD, Chung F, Ayad S, Siddiqui N, et al. Amisulpride for the Rescue Treatment of Postoperative Nausea or Vomiting in Patients Failing Prophylaxis:A Randomized, Placebo- controlled Phase III Trial. Anesthesiology. 2019;130(2):203-12.

Cite this article as: Kumar A, Singh A, Brashier DBS, Karan A, Sharma S, Pratap U. Amisulpride: tackling postoperative nausea and vomiting not a nightmare any more. Int J Basic Clin Pharmacol 2020;9:1167-74. 